\title{
Migration and the crimes of People smuggling and trafficking. Technical-legal analysis
}

\author{
Laidiana Torres Rodríguez \\ Law Deparment, Faculty of Social Sciences and Humanities, University of Pinar del \\ Río, Cuba \\ laidiana.torres@upr.edu.cu
}

\section{Lisett D. Páez Cuba}

Law Deparment, Faculty of Social Sciences and Humanities, University of Pinar del

Río, Cuba

lisett@,upr.edu.cu

\author{
Liliana Margarita Martínez Hernández \\ Publications Deparment, University of Pinar del Río, Cuba \\ liliana.martinez@upr.edu.cu
}

\begin{abstract}
In this paper, a technical and legal analysis of the crimes of people trafficking and smuggling associated with migration was made, according to the mistaken regulations in the Cuban Penal Code. For that reason theoretical and empirical methods were used. A proposal for improving the regulation of the crimes of people trafficking and smuggling associated with it in the Cuban Penal Code was established, in order to a future amendment. It was analyzed the migration as a social phenomenon with a lot of legal and criminal consequences. In addition, the crimes of people trafficking and smuggling associated with it were defined and compared; and it was made a study from the comparative law about the regulation of these crimes in the foreign legislations.
\end{abstract}

Keywords. Migration, People smuggling, People trafficking.

\section{Introduction}

Migration is a phenomenon that has existed in society for many, many years, and has now become more common, as many people migrate from country to country every day. The importance of the study of migration is extremely high because it not only brings with it social consequences but also legal-criminal ones, the latter reflected in the legal norms that regulate the crimes associated with migration and that therefore affect the normal migratory traffic that can arise in any country; specifically the crimes that we will address in this work will be People smuggling and trafficking in a specific way, since generically there are many others that also affect the normal migratory traffic.

The Cuban Penal Code does not provide a unitary treatment under the same title of the crimes associated with migration that it regulates, since it only includes the crime of people trafficking as that, which affects normal migratory traffic, in Title XV. This means that crimes 
affecting this same legal asset, which is so badly needed because of all the changes taking place in Cuba in the area of migration, are not treated correctly.

In view of the above, this research states as a scientific question: How can we contribute to the improvement of the technical-legal regulation of the crimes of People trafficking and smuggling associated with migration, in such a way that normal migratory traffic is articulated as a legal good in Cuban criminal law?, having as objective to establish the theoretical-doctrinal assumptions that support an adequate technical-legal regulation of the crimes of Human trafficking and smuggling associated with migration in Cuban criminal law.

To this end, a study of the theoretical and conceptual framework is made for determining the essential characteristics of migration and the crimes of people smuggling and trafficking associated with it. An analysis is made of the main current trends in foreign legislation on the regulation of crimes associated with normal migratory trafficking. In addition, a technical-legal basis is developed for the crimes associated with migration that contribute to the improvement of their regulation in the Cuban Criminal Code. To achieve the above, various scientific methods are used, such as the dialectical materialist method, documentary analysis, comparative law, theoretical-legal, documentary review and induction-deduction, among others.

The application of these methods is intended to obtain results such as, systematizing the essential characteristics of migration and the crimes associated with it, specifically the crimes of peoples smuggling and trafficking; systematizing, in addition, the main current trends in the regulation of crimes associated with normal migratory traffic; establishing the main manifestations of irregularities in the regulation of crimes affecting normal migratory traffic in the Cuban Penal Code; and also determining the technical legal analysis associated with migration in Cuban penal law.

\section{Theoretical considerations on migration and associated crimes}

Human migration, which refers to the migration of populations of human beings, has two meanings: a broad one, which includes all types of movements of human beings, and another, more restricted one, which only takes into account those movements that involve a change of residence of those who make them. (Casassas, Aviles, 2005).

Any migratory process involves two concepts: emigration and immigration. Emigration is the departure of people from a country, place or region to settle in another country, place or region. Emigration implies a negative estimate of a person's standard of living and family environment and a perception that by settling elsewhere, their economic, social or other prospects will increase or, at least, that their hopes for a better life will be realized in the future.

Immigration is the entry into a country or region of people who were born or come from elsewhere. It represents one of two options or alternatives to the term migration, which is applied to the movement of people from one place to another and these movements entail a change of residence, either temporary or permanent.

So emigration leads to subsequent immigration into the country or place of arrival.

"The most important form of migration from the 19th century to the present day is what is known as the rural exodus, which is the massive movement of inhabitants from the rural to the urban environment: millions of people move annually from the countryside to the city in all countries of the world (especially in underdeveloped countries) in search of better living conditions and, above all, greater employment opportunities" (Argoti, 2015).

Types of migration according to the time:

- Temporary migration: when the migrant is going to be at the destination for a period of time and then returns to his/her place of origin. 
- Permanent migration: when the migrant is going to be in the place of destination permanently or for life.

According to its character:

- Forced migration: when the migrant leaves his place of residence because of situations that threaten his life or against his will. For example: armed conflict or natural disasters.

- Voluntary migration: When the migrant leaves his /her place of residence of his/her, own free will in search of a better quality of life.

Types of migration depending on the destination:

- Internal migration: when the migrant's place of destination is within the same country, that is, he or she moves to another region or place.

- International migration: when the migrant's place of destination is a different country" (Argoti, 2015).

Migration is a highly complex demographic phenomenon that has a variety of causes that are very difficult to determine, especially since, due to irregular migration or migration disguised as tourism or other activities, quantitative data are difficult to obtain, especially in the case of underdeveloped countries. They respond to the widespread concern of human beings to always seek a better place to live since, as Pierre George points out: "The most inevitable (ineluctable in the original) source of inequality between men is their place of birth" (Castilla, 2015) and migration is an attempt to overcome this inequality. The causes that provoke migration are diverse, they can be: political, cultural, socioeconomic and family. Political causes refer to the causes arising from the political crises that often occur in certain countries. Many people who fear political persecution and revenge leave one country to take up residence in another, or at least try to leave, although often they may even lose their lives in the case of totalitarian regimes. When people migrate because of political persecution in their own country, they are referred to as political exiles.

On the other hand, there are the cultural causes of migration. The cultural base of a given population is a very important factor in deciding which country or place to migrate to. Culture (religion, language, traditions, customs, etc.) significantly influences the decision to stay in a country or to migrate from it. Educational possibilities motivate migrants to move from one place to another. In the rural exodus, this factor is often a determining factor, since those who migrate from the countryside to the city are usually young adults, who are more likely to have small children.

Socio-economic causes are generally the root causes in any migration process. There is a direct relationship between socio-economic development and immigration, and therefore between underdevelopment and emigration. Most of those who migrate do so for economic reasons, seeking a better standard of living, better working conditions and remuneration, or in more critical cases, access to employment. The situation of hunger and misery in many underdeveloped countries forces many migrants to risk their lives and even lose them on many occasions, seeking to improve their living conditions.

Family ties are also an important factor in the decision to emigrate, especially in more recent times when migrants from underdeveloped countries need a lot of help to settle in more economically developed countries. In addition, the causes of war and other international conflicts are a real source of forced migration, which has given rise to mass displacement, fleeing extermination or persecution.

There are also so-called environmental migrations, that is, those caused by natural phenomena. The effects of major earthquakes, floods, prolonged droughts, cyclones, tsunamis, epidemics and other natural and social disasters (or a combination of both, which is much more frequent) have caused large movements of human beings (we could also consider them as forced 
migrations) during all periods, aggravated in recent times by population growth and the occupation of areas at greater risk of such disasters. This scenario makes it very difficult, if not impossible, to differentiate between the causes of migration caused by natural disasters and those of other kinds. A low-intensity earthquake, for example, can be very destructive in underdeveloped countries with poor housing and no major social and economic organization; while in more developed countries, another earthquake of the same intensity can have almost no negative consequences in terms of the country's infrastructure and loss of life.

In relation to the consequences they bring, these can be direct and indirect, both in the countries or areas of emigration and in those of immigration, and in both cases, they can have both positive and negative effects:

For the place of emigration, the following are positive consequences:

- The alleviation of some overcrowding problems.

- The achievement of greater cultural or political homogeneity (the most dissatisfied are those who first migrate, leaving only the conformists, who usually agree with their socioeconomic or political situation).

- The reduction of demographic pressure on resources.

- The investment of remittances sent by migrants.

- The decrease in unemployment.

- The increase in productivity as the active population decreases in the country of emigration.

- The increase in the sale of products in other countries, especially in the countries receiving the emigrants.

These situations cause multiple problems in families (negative consequences), ranging from an ageing population (due to the departure of young people of childbearing age), a decline in school performance and schooling in general (due to a general decrease in enrolment), a decrease in public revenue (due to the emigration of working people), etc.

Positive consequences for the place of immigration are: the rejuvenation of the population; the population becomes more open to change (social, cultural, technical); contributions of capital and labor; contributions of new techniques (technological innovation): people who are already prepared arrive without having to invest in their preparation; cultural diversity increases, so the country begins to have access to new cultural manifestations (architecture, art, new technologies, etc.); consumption increases.

Some of the negative consequences are that: Imbalances may appear in terms of age and gender structure; they introduce greater political, linguistic and religious diversity, leading to the formation of completely segregated and marginalized groups; it harms the working class' union consciousness, as immigrants tend to accept lower wages than the local population; it increases the need for services, especially welfare and education; It increases imports of products from the places of origin of the immigrants; remittances to the places of origin of the immigrants; decrease of the salaries in some branches or sectors due to the labor exploitation of the immigrants, since they do not have documents authorizing such migration, this country can decide whether to expel the emigrant or not. (Argoti, 2015)

\subsection{Crimes associated with migration}

Illegal people trafficking and/or illegal migrant trafficking are terms used to describe the transportation of people, for a variety of reasons, across international borders to an unofficial point of entry in a destination country. Typically, those being transported may not have proper documents to travel formally or may not have prior approval to enter the destination country. 
People who transport migrants illegally are often also many people who are transported and thus seek to improve their employment and financial opportunities. But with increasing restrictions in global refugee policy, illegal immigrants fleeing persecution or extreme living conditions are often interpreted as mere economic migrants.

The United Nations Protocol to Prevent, Suppress and Punish People smuggling, Especially Women and Children defines trafficking of migrants as the "procurement, in order to obtain, directly or indirectly, a financial benefit of a material nature, of the illegal entry of a person into a State party of which the person is not a national or a permanent resident" (Derecho, 2005).

Interpol, in a recent statement, describes people trafficking as: "Illegal human trafficking has become the preferred trade of a growing number of criminal networks worldwide that are showing greater sophistication in moving large numbers of people with a higher profit margin than ever before.

In the southwestern United States, a "coyote" is a person who is paid to smuggle illegal immigrants across the U.S.-Mexico border. Snakeheads" are undercover individuals who transport people from China to the United States and other countries. (Ramonet, 2011)

For its part, people smuggling or people commerce is the illegal trade in persons for the purposes of reproductive slavery, sexual exploitation, forced labor, organ removal, or any modern form of slavery. It is considered as the modern-day slavery, human trafficking involves the buying and selling of people, where the victim is subject to the authority of another subject.

Snakeheads are undercover individuals who transport people from China to the United States and other countries. Considered to be modern slavery, people smuggling involves the buying and selling of persons, where the victim is subject to the authority of another subject.

It is an international crime against humanity and violates the human rights of the person who suffers it, also called XXI (Ramonet, 2014) century slavery. It is a violation of human rights that violates the freedom and dignity of the victims enshrined in the Constitution. It involves the capitulation and illegal transportation of humans.

"Victims of smuggling are often recruited through deception (such as false offers of work or misleading offers that do not make clear the conditions under which the offered work will be done) and transported to the place where they are exploited. In places of exploitation, victims are held by their captors through threats, debts, lies, coercion, violence, among other mechanisms, and are forced into prostitution or work in subhuman conditions. (Agape, 2014)

The United Nations Protocol to Prevent, Suppress and Punish Trafficking in Persons, Especially Women and Children (better known as the Trafficking in Persons Protocol) was adopted in Palermo, Italy in 2000, and is an international agreement attached to the United Nations Convention against Transnational Organized Crime. The Trafficking in Persons Protocol is one of the three protocols applied to complement the Convention.

The United Nations Convention against Transnational Organized Crime defines trafficking in persons as: "the recruitment, transportation, transfer, harboring or receipt of persons, by means of the threat or use of force or other forms of coercion, of abduction, of fraud, of deception, of the abuse of power or of a position of vulnerability or of the giving or receiving of payments or benefits to achieve the consent of a person having control over another person, for the purpose of exploitation.

Exploitation shall include, at a minimum, the exploitation of the prostitution of others or other forms of sexual exploitation, forced labor or services, slavery or practices similar to slavery, servitude or the removal of organs.

The elements of trafficking in persons are: 
1. The act (what is done): the action of capturing, transporting, transferring, welcoming or receiving people.

2. The means (how it is done): threat or use of force, coercion, abduction, fraud, deception, abuse of power or of a situation of vulnerability, or the granting of payments or benefits in exchange for control of the victim's life.

3. Purpose (why it is done): for purposes of exploitation, which includes prostitution, sexual exploitation, forced labour, slavery, removal of organs and similar practices.

There is exploitation in any of the following cases: (a) When a person is reduced or kept in slavery or servitude or is subjected to similar practices; (b) When a person is forced to perform forced labour or services.

It can also be ordered according to the order of events:

1. Recruitment, this can be by deception or force and involves a recruiter.

2. Transport, from here to the exploitation the victim is subject to coercion, the transfer can be between regions or to other countries. This process involves transporters, corrupt officials, and the trafficker's intermediaries.

3. Exploitation, here the victim is subjected to exploitation, by the pimp or the exploiter. That the victim is credited with an illegal property right.

Organized crime, immigration and human trafficking are issues that although very different are directly related because sometimes it is the economic situations that force victims to immigrate and after arriving at the site they are subjected to abuse and mistreatment. Using force and manipulation and creating a bond of dependency, traffickers often take over their victims, leaving them with little or nothing to live on.

People smuggling is considered a global phenomenon, with more than 130 countries reporting cases. It is also one of the most lucrative illegal activities, after drug and arms trafficking. "According to UN estimates, more than 2.4 million people are currently being exploited as victims of human trafficking and up to $80 \%$ of human trafficking victims are women and girls.

In relation to the smuggling of children, it can be said that a high number of children suffer as a result. Trafficking for the purpose of sexual exploitation occurs with children working on the streets of cities. Many children from rural areas are taken to the cities by the traffickers. There is evidence that poverty, alcoholism, family dysfunction and violence, drug abuse, sexual abuse make them more vulnerable; just as those who are out of school, on the streets, or in institutions are at high risk.

Generally speaking, "the crime of people smuggling consists of the forcible or deceptive transfer of one or more persons from their place of origin (whether within the country or across borders), the total or partial deprivation of their liberty, and labour, sexual or similar exploitation. It is different from illegal trafficking of migrants, for several reasons:

- Consent: in the case of illegal trafficking of migrants, which is often carried out in dangerous or degrading conditions, the migrants consent to such trafficking. Victims of trafficking, by contrast, have never consented or, if they did initially, that consent has lost all value through coercion, deception or abuse by the traffickers.

- Exploitation: Smuggling ends with the arrival of the migrants at their destination, while trafficking involves the persistent exploitation of the victims in some way to generate illegal profits for the traffickers. From a practical point of view, victims of trafficking are also often more severely affected and in greater need of protection from revictimization and other forms of abuse than clandestine migrants. 
- Transnationality: illegal trafficking is always transnational, while smuggling may not be. It can take place regardless of whether victims are moved to another State or just moved from one place to another within the same State.

From the above, it can be understood that in the case of trafficking it is not indispensable for the victims to cross the borders for the criminal act to take place, while this is a necessary element for the commission of the trafficking.

Although the dominant position expressed distinguishes trafficking from smuggling, depending on whether or not the consent of the immigrant has been obtained or whether or not his or her freedom has been affected, certain doctrines (Hairabedian, 2009) consider that trafficking is a generic term that includes both trafficking in persons (for the purpose of exploitation) and immigrant smuggling (illegal crossing of borders with the consent of the person being transported).

Consequences of trafficking on societies:

- Destabilization of the sexual and labor markets, generating unfair competition (particularly in those States where the sex industry is not penalized)

- Decomposition of the social fabric

- Recovery costs for victims

- Public health risks (STIs, HIV/AIDS, Hepatitis B and C)

- Proliferation and diversification of organized crime and territorial disputes generating conflict and violence

- Money laundering with a clear impact on financial markets

- Increased corruption

- Violation of existing national legislation (against sexual exploitation, labour, migration, human rights laws, etc.)

\section{Normal migratory traffic as a legal asset protected by Comparative law}

The legal regulation of migration-related crimes varies depending on the specific conditions in each country. Briefly, they are regulated as follows:

\begin{tabular}{|l|l|}
\hline Criminal Codes & Crimes: Human trafficking and migrant smuggling \\
\hline Argentine Criminal Code & $\begin{array}{l}\text { It regulates the Crime of Trafficking in Persons in Title III: Crimes } \\
\text { against Social Integrity, Chapter III, articles } 127 \text { paragraphs from the } \\
\text { second to the fourth.1 Article } 127 \text { states that anyone who promotes or } \\
\text { facilitates the entry into or exit from the country of persons under } 18 \\
\text { years of age for the purpose of prostitution shall be punished by } 4 \text { to } \\
10 \text { years' imprisonment, and if the person concerned is over } 18 \text { years } \\
\text { of age, and the penalty in this case, the perpetrator shall be punished } \\
\text { by } 3 \text { to } 6 \text { years' imprisonment. (The article does not expressly state } \\
\text { Trafficking in Persons, but it is inferred that it is that crime by the } \\
\text { elements of criminality present in the figure). }\end{array}$ \\
\hline Colombian Criminal Code & $\begin{array}{l}\text { The crime of trafficking in persons is regulated in Title XI "Crimes } \\
\text { against Sexual Freedom and Human Dignity, Chapter V on Pimping", } \\
\text { in article } 311 \text {, and the sanction regulated by the Code for this crime is } \\
\text { imprisonment from two (2) to six (6) years and a fine equivalent to }\end{array}$ \\
\hline
\end{tabular}




\begin{tabular}{|c|c|}
\hline & $\begin{array}{l}\text { multiplying by an amount of seventy-five ( } 75) \text { to seven hundred and } \\
\text { fifty (750) the value of the current legal monthly minimum wage. }\end{array}$ \\
\hline Costa Rica Criminal Code & $\begin{array}{l}\text { Article } 172 \text { Section III Corruption, Pimpingand Racketeering, in Title } \\
\text { III: Sexual Crimes, criminalizes the crime of trafficking in persons. } \\
\text { This crime is committed by anyone who promotes, facilitates or } \\
\text { encourages prostitution, or to keep them in labour servitude, shall be } \\
\text { punished by imprisonment for three to six years. The penalty shall be } \\
\text { a term of imprisonment of four to ten years, if any of the circumstances } \\
\text { listed under aggravated procuring are present. } \\
\text { Article } 3742 \text { of Title XVII, "Offence against human rights", regulates } \\
\text { the penalty to be imposed on persons who commit the offences of } \\
\text { trafficking in persons and drug trafficking (in the case of persons who } \\
\text { are members of an international organization). } \\
\text { Articles } 376 \text { and } 377 \text { impose the corresponding penalty for trafficking } \\
\text { in minors for adoption and trafficking in persons for the marketing of } \\
\text { their organs, respectively; this is a matter of criticism because, as we } \\
\text { analysed in the previous chapter, these behaviours must be considered, } \\
\text { according to their material element, as a crime of trafficking in persons. } \\
\text { Article } 183 \text { (a) of Title IV, Crimes against the Family, refers to the } \\
\text { penalty to be imposed on violators of the adoption process, which is } 3 \\
\text { to } 8 \text { years' imprisonment for anyone who promotes or facilitates the } \\
\text { departure of minors from the country in contravention of the relevant } \\
\text { immigration provisions. }\end{array}$ \\
\hline Guatemalan Penal Code & $\begin{array}{l}\text { This Code clearly refers to the regulation of the crime of trafficking in } \\
\text { persons in article 1943, Chapter VI, Crimes against Worship, Title III, } \\
\text { Crimes against Liberty and Social Security; the penalty for the } \\
\text { commission of this crime is imprisonment of one to three years and a } \\
\text { fine of five hundred to three thousand quetzals. }\end{array}$ \\
\hline Nicaragua Criminal Code & $\begin{array}{l}\text { The crime of trafficking in persons is regulated in articles } 203,205 \text { and } \\
207 \text {, Chapter IX: Corruption, prostitution, pimping or ruffiancy, } \\
\text { trafficking in persons and sodomy, under the title: "Crime against } \\
\text { persons and their physical, psychological, moral and social integrity". } \\
\text { Article } 2034 \text { refers to the elements of the offence and the penalty for } \\
\text { its commission is four to ten years' imprisonment. } \\
\text { Article } 205 \text { states that the General Procurator of Nicaragua Republic is } \\
\text { responsible for prosecution of this offence ex officio. Article } 207 \\
\text { regulates the punishment of those persons who act as accomplices in } \\
\text { the commission of the offence and have a special relationship with the } \\
\text { victim, and they will be punished as perpetrators. }\end{array}$ \\
\hline Panama Criminal Code & $\begin{array}{l}\text { Article } 310 \text { of this Code defines the crimes of trafficking in persons } \\
\text { and drug trafficking, Chapter III: Crimes against the International } \\
\text { Community, Title IX "Crimes against the Legal Personality of the } \\
\text { State", when the author is part of an International Organization, the } \\
\text { penalty is } 10 \text { to } 15 \text { years in prison. }\end{array}$ \\
\hline
\end{tabular}


Article 310 A regulates the crime of trafficking in persons, which is correctly regulated because it covers the elements of this type of crime; the penalty is 5 to 10 years' imprisonment.

Broadly speaking, the following can be deduced from the comparative legal study:

- The Criminal Codes of the various countries that were analyzed, most of them the crime that regulates of the two that are the object of this work is the People smuggling; except the Criminal Code of Panama that regulates the Trafficking in Persons and manages to do it correctly. The Criminal Code of Costa Rica has included both offences in its articles, but an analysis of these regulations shows that they really only regulate smuggling in persons, since what qualifies as trafficking in persons is compatible with people smuggling, since in this case the purpose of the article is to market the organs of a minor.

- According to the title of the Code where the crimes of People smuggling and trafficking are different: the Crime of People smuggling appears in all of them, which protects sexual relations, but the wording as such of the title is different in all cases; while the Code of Panama, as it regulates the Crime of people trafficking, includes it in the title: Crimes against the Legal Personality of the State.

- With regard to the penalty imposed for committing the offences already mentioned, the penalty for People smuggling ranges from 2 to 6 years' imprisonment, except in Guatemala, which ranges from 1 to 4 years' imprisonment and a fine of between 500 and 3,000 quetzals, which is the lowest penalty, and in Nicaragua, which ranges from 4 to 10 years' imprisonment, which is the highest penalty. The offence of People trafficking, which is regulated by the Code of Panama, is punishable by 5 to 10 years' imprisonment, and is aggravated by 10 to 15 years' imprisonment if the perpetrator belongs to an international organization.

- With the exception of the Argentine Criminal Code, the rest of the articles of the Code refer literally to the type of offence; it is not at all difficult to identify it because its elements of criminality do not lead to confusion.

\section{Technical-legal analysis of migration-related crimes in Cuban criminal law}

Title XV of the Cuban Criminal Code regulates offences against normal immigration traffic, and the only offence it defines under this title is the offence of People trafficking. We consider this issue to be worthy of criticism since our criminal law regulates other crimes under different headings than those mentioned above, which effectively affect normal migratory traffic.

The normal migratory traffic is not more than the different actions that can be made by certain people do not go against the established in the migratory laws, that the migrations take place of legal form fulfilling all the anticipated steps without breaking them.

The legal good protected in Title XV "is the normal development of the migratory traffic and the protection of the rights of the people who are object of the illicit traffic of migrants that given the complexity and the forms of commission of these crimes are needed of a special protection on the part of the state through the mechanisms of the penal law, that in this case is necessary because it is a question of harmful conducts to legal-criminal transcendent goods for the legal security of the State and the human rights of the citizens, consecrated constitutionally".

In the international community we have organizations such as the United Nations Convention against Transnational Organized Crime and the Protocol against the Smuggling of Migrants by Land, Sea and Air and to prevent, suppress and punish trafficking in persons, especially women and children. Both regulate in detail the Crimes of Trafficking and Smuggling of Persons. 
In our country, illegal migration is mainly to the United States and, despite the fact that both countries have concluded agreements to eradicate these behaviors, they are not complied with by the United States. What they have done is to encourage illegal departures in our country, encouraged by the guarantees that the U.S. government provides to them when they leave Cuba illegally; the Cuban Adjustment Act is a faithful reflection of this.

The crime of People trafficking is regulated in articles 347 and 348 of the Cuban Penal Code, the only crime in the title of the Code that is analyzed as stated above. The typical conduct of this crime is organizing and promoting acts of illegal entry into and exit from the national territory with the aim of emigrating for profit.

The active subject of this crime is of a general nature because it can be committed by any person, but without being legally empowered to do so; this is striking, because if the person who commits the acts is empowered to carry out immigration procedures in no case would it be to organize and promote for profit, then another criminal figure related to the subject's specialty could be considered. In this regard, the wording of the provision is not correct, since no person is legally authorized to perform the acts described in article 347 of that law for profit.

In the second paragraph of Article 347 it is stated that the departure for emigration is from the national territory to third countries, which implies transit through a third country. If the article were to be worded as follows: third countries, the name would have to be changed to receiving country.

The subjective element of this figure is the specific malice because the profit motive for which this figure is characterized manifests a fraudulent conduct, requiring in addition the knowledge of the action being performed that it has a specific purpose.

The figure provided for in article 348 is made up of a general subject characterized by the conduct that leads to the penetration of the national territory, as a material element of the offence, using a ship or aircraft or other means of transport, for the purpose of carrying out the illegal departure of persons from the national territory. It is a crime of ulterior intention, in which it is not necessary for the purpose to be achieved for it to be considered consummated.

In our opinion, the following crimes, which are regulated under other titles of the Cuban Penal Code, should be regulated under Title XV: "Crimes against normal migratory traffic", because they are associated with migration and their commission goes against the legal right protected by this title. These are essentially the crimes of illegal entry into and departure from the national territory and trafficking in persons. The following is a technical legal analysis of each of them:

The crime of illegal entry into and exit from the national territory is regulated by the title "Crimes against public order", Chapter XI, articles 215, 216 and 217. Article 215 (1) consists of entering the country without complying with the legal formalities; it is a generic crime of fraud, since it is necessary to bear in mind the intention behind the entry; if it is for the extraction of illegal immigrants, we are dealing with the crime of human trafficking. Paragraph 2 is a cause for justification that corresponds to the right of asylum provided for in our Constitution.

The basic concept of Illegal Departure from the National Territory is regulated in article 216.1, which consists of carrying out acts aimed at leaving the national territory without complying with legal formalities; it is a concept of early completion, given that it would be absurd to punish anyone who leaves the national territory. At present, those who carry out these acts, far from being subjects of crime, are the object of United States propaganda campaigns, which lead to the loss of human life. The majority of illegal immigrants are now the target of crimes such as human trafficking.

Paragraph 2 is an aggravated figure; paragraph 3 is an exception to article 10.1 (a) of the Cuban Penal Code. 
Article 217, paragraph 1, it is an intentional crime of generic fraud, which differentiates it from the crime of People trafficking, since the latter is specific fraud with a view to profit.

The crime of People smuggling is regulated in the title: "Crime against the Normal Development of Sexual Relations and against the Family, Children and Youth", in Chapter I: Crimes against the Normal Development of Sexual Relations, Fourth Section, article 302. As explained in previous sections, this offence involves the recruitment, transport, transfer, harboring or receipt of persons, by means of threat, use of force, etc., and the purpose is to exploit those persons who are victims of this offence. In our Criminal Code its regulation is joined in the same article with the Crime of Pimping. Paragraph 3 (a), because of the typical conduct it regulates, can be said to refer to the crime of trafficking in persons. This crime should be regulated in the title referring to the crimes against the normal migratory traffic because its commission affects the correct migratory process when taking place the entrance and exit of people from a territory to another one for exploitation purposes.

Another crime indirectly associated with migration is money laundering. This crime is closely related to the crimes that affect the normal migratory traffic and therefore we consider that it should be regulated in this title and not where it is criminalized.

At the present time there are huge sums of money being obtained from trafficking in drugs, persons, arms or other offences related to organized crime, the precursors of which, in an effort to make the proceeds of crime profitable, incorporate the income obtained, "dirty" or "black", into the economies of the different countries with the aim of laundering or laundering their capital. This process is called "money laundering".

The typical conduct of this crime is the acquisition, conversion, and transfer of illicitly obtained capital. The material object of the crime according to our legislation is constituted by resources, goods (any valuable benefit in economic form) or rights. It is a fraudulent crime according to its subjective element, specifically eventual fraud. In the case of our country, normative precisions are necessary for the formulation of this type of subjective crime, particularly taking into account the content of the will.

Nevertheless, it is considered that the crimes directly associated with migration are People trafficking and People smuggling, although there are others such as money laundering that are indirectly associated with this socio-legal phenomenon. Therefore, after analyzing the criminal figures specifically associated to migration, it is considered that these should be regulated in the title that regulates the crimes that affect the normal migratory traffic.

In order to deal with migratory crimes, what is most needed, in a special way, is multilateral cooperation, fundamentally from the most developed states, to mitigate the factors that, such as poverty, underdevelopment and lack of equitable opportunities exist in many countries, make people vulnerable to legal trafficking, especially women and children.

\section{Conclusions}

Migration is a phenomenon that should be studied because of its relevance to society. The causes that provoke it are dissimilar: socio-economic, political, cultural and family. The crime of People Trafficking consists of: the facilitation of a border crossing without complying with legal or administrative requirements in order to obtain directly or indirectly an economic or other material benefit; while the Crime of People smuggling is:the recruitment, transportation, transfer, harboring or receipt of persons, by means of the threat or use of force or other forms of coercion, of abduction, of fraud, of deception, of the abuse of power or of a position of vulnerability or of the giving or receiving of payments or benefits to achieve the consent of a person having control over another person, for the purpose of exploitation. 
The crimes associated with migration that are analyzed from the point of view of Comparative law vary in terms of the framework of sanctions in the different legislations and the titles of the Codes within which they are regulated are different. The Cuban Criminal Code regulates the crime of trafficking in persons under the title "Crimes against Normal Immigration Traffic", to which other crimes under other titles of the Code must be added, such as: Illegal Departure from and Entry into the National Territory, People smuggling and Money Laundering.

\section{References}

[1] Aja, A. (2010): Los Estados Unidos-Cuba, Emigración y relaciones bilaterales. In: Revista Temas, No.62- 63, abril- septiembre.

[2] Aja, A. \& Rodríguez, M. (2013): Ley de Ajuste cubano. Antecedentes y particularidades. Folleto La Ley Helms- Burton, publicado en enero por la Unión Nacional de Juristas de Cuba.

[3] Amnistía Internacional (2013): El Estado de los Derechos Humanos en el mundo. Edición y traducción al español: Editorial Amnistía internacional (EDAI), Valderribas, Madrid.

[4] Baucells, J. \& García, M. (2008): La amortización de las normas penales en materia de trata. In: I Jornada de acción contra la trata en Defensa de los Derechos de las Mujeres, 27 de junio, Barcelona.

[5] Carbonell, J. C. (2001): Reflexiones sobre el abuso del Derecho Penal y la banalización de la legalidad. En Homenaje al Dr. Marino Barbero Santos in memoriam. Ediciones de la Universidad de Castilla- la Mancha, Ediciones Universidad, Salamanca, Cuenca.

[6] Colectivo de Autores (2005): Derecho Penal Especial, Tomo I y II. La Habana, Cuba: Editorial Félix Varela.

[7] De la Cruz Ochoa, R. (2007): Delitos de trata y tráfico de personas. In: Revista Cubana de Derecho, No.30, julio- diciembre. La Habana, Cuba.

[8] García, S. (2008): Inmigración ilegal y trata de personas dela Unión Europea: la desprotección de las Víctimas. In: Revista de Derecho Constitucional Europeo, Año 5, No.10, julio- diciembre.

[9] Grillo, J. A. (1983): Los delitos en especie. Tomos I, II y III. La Habana, Cuba: Editorial Pueblo y Educación.

[10] Hairabedian, M. (2009): Tráfico de personas. La trata de personas y los delitos migratorios en el derecho penal argentino e internacional. Buenos Aires, Argentina: Editorial Ad Hoc.

[11] Medina, A. 2013.: Cuba, el delito de tráfico ilícito de personas y la necesidad de su actualización en el Código Penal. In: Revista Cubana de Derecho, No.41, enero-junio.

[12] Morillas, L. (2005): "El Derecho Penal mínimo o la expansión del Derecho Penal", In: Revista Cubana de Derecho, No. 25, enero- junio.

[13] Oficina de Las Naciones Unidas Contra La Droga y el Delito (2000). "Convención de las Naciones Unidas contra la delincuencia organizada transnacional y sus Protocolos”. Aprobada en noviembre por la Asamblea General de las Naciones Unidas.

[14] Peñarroche, M. \& Pérez, I. M. (2013): La trata y tráfico de personas. Su regulación internacional y en Cuba. In: Revista de la Fiscalía General de la República de Cuba Legalidad Socialista, No. 7.

[15] Pérez, A. I. (2002): Algunas consideraciones político criminales previas a incriminación de las personas. In: REDUR, junio.

[16] Pérez, P. (2012): Las conferencias iberoamericanas. Una reflexión desde 2012. In: 
Revista Real Elcano.

[17] Rodríguez, M. J. (2001): Delitos contra los derechos de los ciudadanos extranjeros. Valencia, España: Editorial Tirant lo Blanch.

[18] Silvera, O. M. \& Bertot, M. C. (2012): Apuntes acerca del tráfico de personas en la legislación actual cubana. In: Boletín ONBC, No.43, enero-marzo, Ediciones ONBC.

[19] Terradillos, J. M. (2001): Sistema penal y criminalidad internacional, en Homenaje al Dr. Marino Barbero Santos. In Memoriam, vol. I, Cuenca.

[20] Torres, L. \& Páez, L. D. (2018). El impacto jurídico de las migraciones en Cuba. Una propuesta para la regulación de los delitos de Trata y Tráfico de Personas. In: Revista Novedades en población. Volumen 14, No. 28, julio - diciembre.

[21] Villacampa, C. (2004): Trata de seres humanos y delincuencia organizada. Conexión entre ambos fenómenos criminales y su plasmación jurídico penal. In: Revista para el análisis del Derecho, No. 1, Universitat Pompeu Fabra.

[22] Zaffaroni, E. R. (2007): Globalización y crimen organizado. In: Conferencia de clausura de la primera Conferencia Mundial de Derecho Penal, organizada por la Asociación Internacional de Derecho Penal (AIDP), pronunciada el 22 de noviembre, en Guadalajara, Jalisco, México.

[23] Argentine Penal Code (Ley No. 11.179 de 3 de noviembre de 1921)

[24] Colombia Penal Code (Ley No. 599 de 2000 de 24 de julio de 2000)

[25] Costa Rica Penal Code (Ley No. 4573 de 4 de mayo de 1970)

[26] Guatemalan Penal Code (Decreto No. 17- 1973 de 30 de agosto de 1973)

[27] Cuban Penal Code (Ley No. 62 de 29 de diciembre de 1987)

[28] Nicaragua Penal Code (Ley No. 641 de 3 de diciembre de 2007)

[29] Panaman Penal Code (Ley 18 de 22 de septiembre de 1982)

\section{Internet sites}

[30] Ágape: ¿Qué es la Trata de Personas? Retrieved from: http://agapeorgmx.com/que-esla-trata-de-personas/[visited 11/05/2014].

[31] Alcívar Ortiz, M. V. (2004): La migración. Aplicación del protocolo contra el tráfico de migrantes por tierra mar y aire, p.56. Retrieved from: http://repositorio.ug.edu.ec.pdf [visited17/05/2015].

[32] Argoti, V.: Migración Humana. Wikipedia. Retrieved from: http://75.82.149.74:10003/wikipedia es all_11_2013/A/html/M/i/g/r/Migraci $\% \mathrm{C} 3 \%$ B3n_humana.html [visited 11/05/2015].

[33] Casassas, J. \& Avilés, J. (2005): La construcción del presente: el mundo desde 1848 hasta nuestros dias. Barcelona: Ariel. Retrieved from: http://www.bocks.gogle.es/ [visited25/05/2014].

[34] Castilla, G.: Trata de personas. Retrieved from: http://es.slideshare.net/GabrielaRuiz18/trata-de-personas-33005138 [visited 17/05/2015].

[35] Chica, C.: Manifiesto "Todos Son Inocentes" contra la Esclavitud Infantil, Documentos y Manifiesto. Blog de la esclavitud, 2015. Retrieved from: $\quad$ https://derecho59.wordpress.com/doucumentos-y-manifiestos/[visited $17 / 05 / 2015]$.

[36] Convención de las Naciones Unidas contra a Delincuencia Organizada Transnacional, Annex II, Section I, article 3, pp. 44-45. Retrieved from: http://www.unodc.org/documents/treaties/UNTOC/Publications/TOC\%20Conventio n/TOCebook-s.pdf [visited 17/05/2015]. 
[37] Ferro, J. M. (2014): Tráfico de seres humanos únicos testigos. Edición 1, Sección 1, Retrieved

from: http://books.google.com.cu/books?uid=114584440181414684107\&hl=es\&source=g bs_lp_bookshelf_list [visited 17/05/2015].

[38] Fernández, Y., Terán, J., Peinado, D. \& Pobeda, F. (2012): Trata de Personas, Ética y profesionalismo. Retrieved from: http://eticaenlautb.blogspot.com/2012/11/yulikafernandez-jorge-teran-diana.html [visited 17/05/2015].

[39] George, P. (1971): Geografía de la población. Barcelona: Oikos-Tau. Retrieved from: http://es.wikipedia.org/wiki/Geograf\%C3\%ADa_de la poblaci\%C3\%B3n [visited 16/05/2015].

[40] Ley 26.364. Prevención y Sanción de la Trata de Personas y asistencia a sus víctimas. República Argentina, artículo 4. Retrieved from: http://www.infoleg.gov.ar/infolegInternet/anexos/140000144999/140100/norma.htm[visited 17/05/2015].

[41] Ramonet, I. (2011): Tráfico y trata de personas. Esclavos en Europa. Bases de datos legales, ACNUR, Le Monde diplomatique, $\mathrm{N}^{\mathrm{o}}$ : 189 Julio. Retrieved from: http://es.wikipedia.org/wiki/Trata_de_personas [visited 16/05/2014]. 